\& shall see how the matter strikes you: If agreeably further explanations will be made \& with a view to this I am looking into the earlier period of the business in order to show from what it has advanced.

I am very truly yr. ob. s.

Frederic Tudor

\title{
Sources for Maritime History
}

IT Is remarkable to see how the items of manuscript material in a particular field, coming in over a period of years and from numerous sources, do, in the final analysis, dovetail together to form one unified collection. The result is like a piece of mosaic. This is the thing which fascinates the collector. Each item alone may seem more or less insignificant, but the whole is more complete because of the least significant part.

Among the many industries for which Baker Library has been collecting source material, the most romantic and colorful is undoubtedly the shipping industry. Recent acquisitions along this line have so added to the value of this group that it has become an outstanding collection in its field.

The earliest shipping records of any considerable extent came to the Society from Charles $\mathrm{H}$. Taylor. They are the papers of Israel Thorndike and cover the years $1778-1818$. Israel Thorndike was a shipping merchant of Beverly, trading primarily with the West Indies, though he also sent cargoes to England and Mediterranean ports as well as to the East Indies and Calcutta. The papers include letters, accounts of cargoes sold and invoices of goods purchased at various ports, accounts current with captains of vessels, insurance papers, etc. From these records it is possible to learn much about the character of American shipping in the days of its very beginning. We can see the extent to which the merchant was forced to rely on the sagacity of his supercargo, and we see something of the difficulties that confronted him in establishing contacts in foreign countries. Further, the papers in the collection relative to the French Spoliation claims indicate the problems American merchants had to face which were arising out of the Napoleonic Wars.

Another interesting group of shipping papers came to the Baker Library only recently. These are the records of Augustine Heard of Ipswich, Massachusetts. They run back to 1807 , covering first 
his travels as a supercargo for Boston and Salem merchants who were trading in the Far East, then his activities as a partner in the great shipping firm of Russell and Company, and finally his undertaking as an independent merchant. In 1836 he left Russell and Company and by 1840 he had become head of his own firm Augustine Heard and Company, in which Coolidge and Kinsman were partners with him. In the later years of this company the business was carried on by four nephews of Augustine Heard John, Augustine, Albert Farley, and George. The firm finally wound up in bankruptcy in the 'seventies. The first account book of Augustine Heard which we have is for the year 1807, when he was sailing as supercargo on the ship William on a voyage to Calcutta. His accounts of the trip are most systematic and complete. There were nineteen persons sharing in the adventure, investing anywhere from $\$ 300$ to $\$ 20,000$. The total amount transported in Spanish milled dollars was \$90,000, in addition to a considerable quantity of goods. He gives itemized accounts of the sales of goods shipped by various individuals and of the amounts paid for goods purchased with the returns. In the front of the book appear copies of the letters of instruction handed to him by the several individuals participating in the enterprise. We recognize quickly such names as Pickering Dodge, Nathan Robinson, Samuel Endicott, Joseph Lee, William Gray and Israel Thorndike. For the most part these men left much to the discretion of the supercargo, but occasionally, especially by those who had themselves been in the Orient, instructions were given to consult certain of the merchants in Calcutta. Ramdulollday was mentioned in several letters.

A collection of records running almost parallel to these in dates, but differing greatly in type of business, is that of the Tudor papers. Here again we see separate gifts dovetailing together to form a whole. Some years ago Charles $\mathrm{H}$. Taylor gave thirteen volumes of the Tudor Company records covering the years I860-1902. Just a few weeks ago Frederic Tudor, grandson of the great Ice King, deposited with Baker Library the manuscripts which completed the collection, extending the record back to 1804 with accounts of the first business efforts of Frederic Tudor. This collection embodies a most exciting story of the gigantic enterprise of introducing ice into the tropics. However, more will be said of this new collection elsewhere in this Bulletin. The records of the well known shipping merchant of Portsmouth, Jacob Wendell, cover nearly 
the same period as the Heard and Tudor papers, and add information on the specializations of another shipping port of importance.

Another link in the history of American shipping is represented by a few volumes presented by Professor Ephraim Emerton. They are the account books of Ephraim and James Emerton, Salem merchants, for the years 1816 to 1835 , and relate chiefly to trade with the pirate colony of Madagascar. American merchants were shipping hams, mackerel, rum, cotton goods, muskets, gunpowder, swords, epaulets, "rich fringe," lace, looking glasses, etc. (The pirates evidently had a strong streak of vanity.) The supercargo was buying for return freight tortoise shell, ivory, ebony, gum copal, gum arabic, raffia, pepper, horn, and hides.

The papers of Daniel W. Lord of Kennebunkport, Maine, for the years $182 \mathrm{I}-1873$, constitute one of the few manuscript possessions the Library has that relates primarily to trade with Europe. In this group of papers such ports as Liverpool, Antwerp, Hamburg, Havre, and Cadiz are those to which most frequent reference is made.

For a later period the William Appleton and Company papers contribute much information of importance. They concern essentially the clipper-ship era, though there are also earlier papers of great interest. In addition to the account books and letter books of the Boston office there is a great mass of unbound papers, consisting to a large extent of letters and accounts current from agents in various parts of the world. Unlike most of the important firms of the earlier period, this company did not establish its own branches in foreign countries, but relied on establishments that were already going concerns to represent them as agents. Among the most important of these were: Augustine Heard and Company, and Russell and Company, Canton; Wolcott, Bates and Company, Shanghai; Russell, Sturgis and Company, and Peele, Hubble and Company, Manila; Martin Murray and Company, Bombay; and Baring Brothers, Liverpool and London. Carey and Company were their agents in New York, and J. C. Burnham and Company represented them throughout the South - New Orleans, Havana, etc. Mr. Henry Mellus was agent for the company in California, and less well known houses represented them in Matanzas, Pernambuco, Rio Janeiro, Antwerp, etc.

The firm William Appleton and Company was organized in r $84 \mathrm{I}$, when Samuel Hooper and James A. Appleton became partners of William Appleton. The company engaged in shipping the coarser 
textile manufactures along with some raw cotton, grains, and lumber to China and the East Indies, in return for tea, silk, mattings, and rice from China; hemp, sugar, indigo, and coffee from Manila; Malacca tin, pepper, and coffee from Batavia. They bought coffee in Rio Janeiro which they exchanged in New Orleans for cotton to be shipped to Liverpool, sometimes taking cargoes of iron and steel products in exchange, to be brought back to the American market, but more often taking credit to be drawn on in China in payment for goods purchased there. They shipped cargoes of well assorted merchandise to California and brought back hides and gold.

William Appleton withdrew from the company in 1859 . The business was carried on under the new name - Samuel Hooper and Company. Shipping continued to be the dominant interest for some time, but changes characteristic in the history of American shipping occurred, until by the 'seventies the chief investments of the company seem to have been in railroads and manufacturing.

Three other collections of the clipper-ship period are the records of Benjamin Newton of Boston, I843-1864; Dane, Dana and Company also of Boston, 1852-1855; and Silsbee, Pickman and Allen of Salem, 1848-1893. The last named is of special interest, not only because of the extent of the collection, but because it serves well to bring out the essential difference between Boston and Salem shipping. Boston merchants sent homogeneous cargoes made up, for the most part, of textiles with a scattering of half a dozen other commodities. Salem merchants chose miscellaneous cargoes, including in the long list of goods shipped the following articles: kerosene, salmon, lobsters, tobacco, nails, axes, shovels, sewing machines, lamps, ploughs, wagons, doors, windows, chairs, tubs, clothes pins, as well as coarse textiles, such as denims and drills. Their imports were primarily from the Orient. From Calcutta came linseed, castor oil, shellac, India rubber, saltpeter, gunny cloth, jute, goat skins, and buffalo hides; from Chinese ports, matting, tea, sugar, lacquered ware, silks, chinaware, fans, etc. They also carried on extensive trade with South America, importing from Buenos Aires quantities of hides, wool, and horse hair.

Among the most interesting papers in this collection are the very complete records kept by the various captains. They give the full accounts of disbursements at every port visited. It is of ten possible to trace the complete history of a ship, including the cost of construction. Among the company's ships for which the records are 
most complete are the Formosa, Malay, Mindoro, Sooloo, and Panay.

There have been mentioned here only the more extensive collections of shipping records. Individual volumes have been neglected, though they often contribute much of interest. Through the records mentioned we are supplied with some valuable material for every year from 1783 to 1893 . The whole, however, constitutes only the history of the sailing craft in American shipping. The greatest weakness in the collection is the absence of any adequate records of a representative steamship company.

\section{Hacienda Records}

Along with the records of the general store of Alfred and Andres Lefebvre, which were given to the Society by Charles P. Howland and were mentioned in the May Bulletin, came a smaller group of accounts, those of the Hacienda de San Bartolomé del Monte, located in the Provincia de Tlaxcala, Mexico. This second group, which includes 27 volumes - journals, ledgers, and cash books covers the period 1869-1905. The owner of the Hacienda, Don Manuel Fernandez del Castillo, is said to have been the head of one of the oldest and most distinguished families of Mexico and, from the account books, we gather a person of great wealth. On one page of the same account book from which the accompanying illustration was taken the accounts were balanced with the figures $9,699,508.86$ pesos.

The produce of the hacienda included cattle, horses, mules, sheep: goats, pigs, wheat, corn, beans, potatoes, grass, bricks, and lumber. Another product of great importance was pulque, the fermented juice of the maguey, and a very popular drink in Mexico.

A study of these records would almost take one back to the feudal period. Here, as under the feudal system, the owner of the land assumed extensive obligations relative to the welfare of those dependent on him - in turn those dependents never became anything more than dependents. Among these were not only the laborers, who received from 6 to I 25 pesos per month, but those members of the family who were in need. One other duty assumed by the head of the family was his responsibility toward the upkeep of the church. To this he gave heavily and in return received the 